\title{
The effect of fish meal or pea meal on milk fatty acid composition in organic farming
}

\author{
S.A. Adler ${ }^{1,3}$ and Å.T. Randby ${ }^{2}$ \\ ${ }^{I}$ Norwegian Institute for Agricultural and Environmental Research, \\ Bioforsk Arctic Agriculture and Land Use \\ Vågønes, 8076 Bodø, Norway \\ ${ }^{2}$ Norwegian University of Life Sciences, Department of Animal and Aquacultural Sciences \\ 1432 As, Norway
}

\begin{abstract}
Fish meal and pea meal in combination with cereals were formulated to be isonitrogeneous and isoenergetic (NEL) and compared at high (HC) and low concentrate level (LC) in a continuous production experiment with dairy cows in organic farming. Fish meal resulted in significantly higher milk yield (kg) with a lower fat concentration (HC) compared to pea meal. The proportions of oleic acid, vaccenic acid, CLA (LC), DHA, and total long-chain unsaturated fatty acids were significantly higher, and the n-6/n-3 ratio was significantly lower (HC) in milk fat produced on fish meal compared with pea meal. The sensoric quality of milk was not affected.
\end{abstract}

KEY WORDS: fatty acid, protein supplement, fish meal, pea meal, dairy, organic farming

\section{INTRODUCTION}

Feed fatty acid (FA) composition influences the FA composition of cow milk. Diets for dairy cows may be designed to modify the composition of FA in milk, to meet consumers demand for food providing health benefits. Organic farmers in Norway may choose fish meal (FM) or pea meal (PM) as protein supplement to home-grown cereals and grass silage for dairy cows. Fish meal has a higher concentration of protein than PM and it contains more fat with a desirable FA composition. However, feeding FM fat may cause milk fat oxidation and fishy flavour of milk and must therefore be fed in restricted amounts.

\footnotetext{
${ }^{3}$ Corresponding author: e-mail: steffen.adler@bioforsk.no
} 


\section{MATERIAL AND METHODS}

A continuous production experiment was carried out with 32 Norwegian Red dairy cows (62 d.i.m.) in Bodø (Norway; $67^{\circ} 17^{\prime} \mathrm{N}, 14^{\circ} 23^{\prime} \mathrm{E}$ ) during the winter season 2005-2006. A preliminary period of 4 weeks preceded an experimental period of 11 weeks. All feeds except FM were produced organically on Bodin farm. Half of the cows were fed $40 \%$ (HC) concentrates (on energy basis per year) and the other half $10 \%$ (LC). The cows were offered restricted amounts of FM or PM, cereals (Table 1), and mineral and vitamin supplements. Well-preserved grass silage was given ad libitum.

Table 1. Composition of the experimental diets (weighed averages and standard deviation)

\begin{tabular}{|c|c|c|c|c|c|}
\hline Indices & $\mathrm{n}$ & $\mathrm{FM}^{1}$ & $\mathrm{PM}^{2}$ & Cereals $^{3}$ & Silage \\
\hline $\mathrm{DM}, \mathrm{g} / \mathrm{kg}$ & $7,6,6,11$ & $947 \pm 2.3$ & $843 \pm 1.9$ & $848 \pm 5.0$ & $247 \pm 34.5$ \\
\hline $\mathrm{NEL}, \mathrm{MJ} / \mathrm{kg} \mathrm{DM}{ }^{4}$ & $0,0,0,4$ & 8.66 & 8.12 & 7.86 & $5.69 \pm 0.214$ \\
\hline $\mathrm{NH}_{3}-\mathrm{N}, \mathrm{g} / \mathrm{kg} \mathrm{TN}$ & 4 & & & & $7.4 \pm 0.30$ \\
\hline $\mathrm{N}, \mathrm{g} / \mathrm{kg} \mathrm{DM}$ & $2,2,2,4$ & $109 \pm 0.1$ & $40 \pm 0.9$ & $18 \pm 0.23$ & $21 \pm 1.6$ \\
\hline $\mathrm{EE}, \mathrm{g} / \mathrm{kg} \mathrm{DM}$ & $2,2,2,4$ & $67 \pm 0.0$ & $19 \pm 3.1$ & $29 \pm 7.0$ & $34 \pm 2.9$ \\
\hline $\mathrm{NDF}, \mathrm{g} / \mathrm{kg} \mathrm{DM}{ }^{4}$ & & & & & $601 \pm 36.0$ \\
\hline In vitro digest., $\mathrm{g} / \mathrm{kg} \mathrm{DM}$ & $2,2,2,4$ & $613 \pm 20.1$ & $972 \pm 1.9$ & $806 \pm 26.6$ & $752 \pm 1.5$ \\
\hline Starch, g/kg DM & 2 & & $406 \pm 9.2$ & $507 \pm 2.8$ & \\
\hline
\end{tabular}

${ }^{1}$ fish meal, NorsECO, Norsildmel, Egersund (Norway), codfish

${ }^{2}$ pea meal, var. Faust

${ }^{3}$ oats, var. Biri 292 g/kg DM; barley, var. Ven and Lavrans 708 g/kg DM

${ }^{4}$ concentrate values from feed table (www.umb.no) and silage as assessed by NIRS of grass

Milk samples were weekly analysed for concentrations of fat, protein, urea and free fatty acids by infrared (FTIR) scanning (CombiFoss ${ }^{\text {TM }} 5000$, Foss, Denmark) at TINE Dairies Harstad, Norway. Trained panels (The Norwegian Institute for Food and Environmental Analysis, Oslo) evaluated the sensory quality of raw milk.

The gas chromatographic analyses (AsVitas, Oslo) of fatty acid methyl esters (FAME) were performed with a $6890 \mathrm{~N} \mathrm{GC}$ with a split/splitless injector, a 7683B automatic liquid sampler, and flame ionization detection (Agilent Technologies, Palo Alto, CA). Separations were performed with a CP-SELECT CB FOR FAME $(200 \mathrm{~m} \times 0.25 \mathrm{~mm}$ i.d. $\times 0.25 \mu \mathrm{m}$ film thickness $)$ fused silica capillary column (Varian Inc.). Data were analysed using analysis of variance with the GML model procedures of SAS. Results regarding FA composition, milk yields and milk composition were covariance corrected for data from the preliminary period, whereas data pertaining to feed intake and BW changes were analysed without covariance correction. 


\section{RESULTS}

The isonitrogeneous and isoenergetic (NEL) rations of concentrates (Table 2) did not affect the intake of silage. Milk yields were significantly higher for cows fed FM compared to PM at both levels of concentrates, but ECM yields were not significantly different. Milk protein concentration was not affected by type of protein feed but lower concentrations of urea and FFA were found in milk produced with FM compared to PM. Using FM compared to PM at HC reduced milk fat concentration. Milk flavour and odour were equal or better when FM was fed, compared to PM. HC milk tended to be of better flavour and odour than LC milk $(\mathrm{P}=0.17)$.

Table 2. Feed intake and yield for cows fed fish meal (FM) or pea meal (PM) diets

\begin{tabular}{|c|c|c|c|c|c|c|c|c|}
\hline \multirow{2}{*}{ Item } & \multicolumn{4}{|c|}{ HC (high concentrate level) } & \multicolumn{4}{|c|}{ LC (low concentrate level) } \\
\hline & FM & PM & SEM & $\mathrm{P}$ & FM & PM & SEM & $\mathrm{P}$ \\
\hline Protein feed, kg DM & 0.676 & 2.898 & & & 0.397 & 1.685 & & \\
\hline Cereals, kg DM & 3.735 & 1.446 & & & 2.225 & 0.849 & & \\
\hline $\mathrm{N}$ in concentrates, $\mathrm{kg}$ & 0.143 & 0.142 & & & 0.084 & 0.082 & & \\
\hline NEL concentrates, MJ & 35.00 & 34.87 & & & 20.80 & 20.34 & & \\
\hline Silage, kg DM & 13.19 & 13.03 & 0.788 & 0.89 & 13.81 & 13.65 & 0.564 & 0.85 \\
\hline BW change, $g / d$ & 0.018 & -0.151 & 0.0872 & 0.19 & -0.114 & -0.060 & 0.0678 & 0.58 \\
\hline $\mathrm{BCS}^{1}$ change, points $/ 100 \mathrm{~d}$ & 0.28 & 0.00 & 0.154 & 0.23 & 0.06 & 0.28 & 0.080 & 0.08 \\
\hline $\mathrm{NH}_{3}-\mathrm{N}$ rumen fluid, $\mathrm{mM}$ & 2.84 & 3.61 & 0.276 & 0.07 & 2.68 & 3.41 & 0.219 & 0.04 \\
\hline Milk yield, kg & 23.2 & 21.7 & 0.44 & 0.03 & 20.1 & 18.9 & 0.37 & 0.04 \\
\hline Milk yield, kg ECM & 23.0 & 22.5 & 0.46 & 0.46 & 20.0 & 18.9 & 0.45 & 0.12 \\
\hline Milk fat, $\mathrm{g} / \mathrm{kg}$ & 40.0 & 43.0 & 0.65 & 0.006 & 41.2 & 41.5 & 0.76 & 0.75 \\
\hline Milk protein, $\mathrm{g} / \mathrm{kg}$ & 32.3 & 32.2 & 0.41 & 0.80 & 30.7 & 31.1 & 0.28 & 0.33 \\
\hline Milk urea IR, mM & 5.41 & 5.58 & 0.05 & 0.03 & 4.90 & 5.12 & 0.08 & 0.06 \\
\hline Milk FFA, meq/L & 0.72 & 0.86 & 0.023 & 0.001 & 0.81 & 0.92 & 0.061 & 0.23 \\
\hline Milk flavour and odour ${ }^{2}$ & 4.25 & 4.01 & 0.127 & 0.20 & 4.02 & 3.85 & 0.147 & 0.44 \\
\hline
\end{tabular}

${ }^{1}$ five point scale with 0.25 point intervals, where $1=$ emaciated and $5=$ very fat animals

${ }^{2}$ five point scale, where $1=$ poor quality milk and $5=$ high quality milk

Fish meal diets increased the proportions of the long-chain FAs oleic acid (C18:1c9), vaccenic acid (C18:1c11), CLA (C18:2c9,t11) at LC, C20:0, C18:1t10, and DHA (C22:6 n-3) in milk fat compared to PM diets (Table 3). DHA, which is found in high concentrations in FM (14 g/100g FAME), had the most significant increase. The percentage of saturated FA was significantly lower and the percentage of monounsaturated FA was higher when FM rather than PM was fed. For cows on $\mathrm{HC}$ the $\mathrm{n}-6 / \mathrm{n}-3$ ratio was lower in the FM group than in the PM group, and the ratio was lower at $\mathrm{LC}$ than at $\mathrm{HC}(\mathrm{P}=0.006$, interaction $\mathrm{P}=0.02)$. 


\section{DISCUSSION}

Fish meal is rich in DHA and increased the proportion in milk directly, in accordance with Abu-Ghazeleh et al. (2001). The higher concentrations of C18:1 acids found in milk from FM diets compared with PM diets could be due to the higher amount of oats kg DM: 1.091 in FM diets vs 0.422 in PM diets, LC: 0.650 in FM diets vs 0.248 in PM diets, which contains high concentrations of oleic acid. This may have led to a more effective CLA synthesis when FM diets were fed.

Table 3. Composition of fatty acids (FA) at high (HC) and low level of concentrates (LC) of milk fat for cows fed fish meal (FM) or pea meal (PM) diets

\begin{tabular}{|c|c|c|c|c|c|c|c|c|}
\hline \multirow{2}{*}{ Item } & \multicolumn{4}{|c|}{$\mathrm{HC}$} & \multicolumn{4}{|c|}{$\mathrm{LC}$} \\
\hline & FM & $\mathrm{PM}$ & SEM & $\mathrm{P}$ & FM & $\mathrm{PM}$ & SEM & $\mathrm{P}$ \\
\hline Milk fat, $\mathrm{kg} / \mathrm{d}$ & 0.94 & 0.96 & 0.025 & 0.53 & 0.84 & 0.81 & 0.025 & 0.36 \\
\hline \multicolumn{9}{|l|}{ FA, g/100 g FAME ${ }^{1}$} \\
\hline $\mathrm{C} 4: 0$ & 4.03 & 4.04 & 0.097 & 0.92 & 4.12 & 4.06 & 0.083 & 0.58 \\
\hline C6:0 & 2.41 & 2.40 & 0.024 & 0.81 & 2.34 & 2.35 & 0.032 & 0.81 \\
\hline $\mathrm{C} 8: 0$ & 1.45 & 1.44 & 0.013 & 0.38 & 1.35 & 1.38 & 0.029 & 0.44 \\
\hline $\mathrm{C} 10: 0$ & 3.55 & 3.38 & 0.037 & 0.61 & 3.00 & 3.17 & 0.099 & 0.25 \\
\hline C12:0 & 3.85 & 3.94 & 0.053 & 0.26 & 3.43 & 3.64 & 0.125 & 0.25 \\
\hline $\mathrm{C} 14: 0$ & 12.61 & 12.57 & 0.128 & 0.83 & 12.00 & 12.31 & 0.300 & 0.48 \\
\hline C14:1c9 & 1.05 & 1.05 & 0.033 & 0.98 & 1.08 & 1.03 & 0.03 & 0.39 \\
\hline $\mathrm{C} 15: 0$ & 1.28 & 1.44 & 0.024 & $<0.001$ & 1.40 & 1.47 & 0.026 & 0.07 \\
\hline $\mathrm{C} 16: 0$ & 32.80 & 34.97 & 0.285 & $<0.001$ & 33.47 & 34.73 & 0.609 & 0.17 \\
\hline C16:1c9 & 1.24 & 1.30 & 0.035 & 0.24 & 1.39 & 1.41 & 0.045 & 0.74 \\
\hline C17:0 & 0.56 & 0.61 & 0.008 & $<0.001$ & 0.59 & 0.63 & 0.008 & 0.01 \\
\hline C18:0 & 8.60 & 7.88 & 0.154 & 0.01 & 8.24 & 7.84 & 0.151 & 0.10 \\
\hline C18:1t10 & 0.18 & 0.12 & 0.008 & $<0.001$ & 0.16 & 0.11 & 0.005 & $<0.001$ \\
\hline C18:1t11 (TVA) & 1.05 & 1.04 & 0.030 & 0.72 & 1.21 & 1.19 & 0.035 & 0.64 \\
\hline C18:1c9 & 15.40 & 14.06 & 0.257 & 0.003 & 15.83 & 14.92 & 0.276 & 0.04 \\
\hline C18:1c11 (VA) & 0.56 & 0.43 & 0.012 & $<0.001$ & 0.56 & 0.47 & 0.013 & $<0.001$ \\
\hline C18:2c9,12 n-6 & 0.93 & 0.99 & 0.019 & 0.03 & 0.79 & 0.81 & 0.015 & 0.55 \\
\hline C18:2c9,t11 (CLA) & 0.53 & 0.50 & 0.012 & 0.08 & 0.60 & 0.56 & 0.011 & 0.05 \\
\hline C18:3 n-3 (ALA) & 0.39 & 0.45 & 0.011 & 0.003 & 0.41 & 0.44 & 0.010 & 0.05 \\
\hline C20:0 & 0.24 & 0.15 & 0.005 & $<0.001$ & 0.21 & 0.14 & 0.005 & $<0.001$ \\
\hline C20:4 n-6 (ARA) & 0.06 & 0.06 & 0.004 & 0.29 & 0.06 & 0.06 & 0.003 & 0.46 \\
\hline C20:5 n-3 (EPA) & 0.12 & 0.09 & 0.007 & 0.07 & 0.10 & 0.11 & 0.008 & 0.54 \\
\hline C22:6 n-3 (DHA) & 0.10 & 0.03 & 0.003 & $<0.001$ & 0.06 & 0.02 & 0.003 & $<0.001$ \\
\hline saturated & 71.21 & 72.78 & 0.444 & 0.03 & 70.13 & 71.73 & 0.443 & 0.02 \\
\hline mono-unsaturated & 19.43 & 18.04 & 0.278 & 0.004 & 20.26 & 19.11 & 0.311 & 0.02 \\
\hline poly-unsaturated & 2.11 & 2.13 & 0.037 & 0.79 & 2.01 & 1.99 & 0.030 & 0.66 \\
\hline$n-6 / n-3$ & 1.66 & 1.85 & 0.039 & 0.006 & 1.50 & 1.52 & 0.030 & 0.61 \\
\hline
\end{tabular}

${ }^{1}$ fatty acid methyl esters 


\section{CONCLUSIONS}

Fish meal compared to PM did not affect silage intake or ECM yield significantly but increased milk yield and decreased fat concentration in milk at $\mathrm{HC}$ level. Fish meal diets increased the proportion of beneficial FA without reducing the sensory quality of milk. It remains unclear whether the effect of FA composition was caused by the protein source or by the higher oat proportions in FM diets.

\section{REFERENCES}

Abu-Ghazaleh A.A., Schingoethe D.J., Hippen A.R., 2001. Conjugated linoleic acid and other beneficial fatty acids in milk fat from cows fed soybean meal, fish meal, or both. J. Dairy Sci. $84,1845-1850$ 